Costales, A. B. and V. P. Veracion (1978): Germination of Benguet pine seeds at various intervals of watering. Sylvatrop 3(4): 243-245.

CzABATOR, F. J. (1962): Germination Value: an index combining speed and completeness of pine germination. Forest Science 8: 386-396.

GinwaL, H. S. and M. GERA (2000): Genetic variation in seed germination and growth performance of 12 Acacia nilotica provenances in India. Journal of Tropical Forest Science 12(2): 286-297.

Ginwal, H. S., P. S. Rawat and R. L. SRIvastava (2004): Seed source variation in growth performance and oil yield of Jatropha curcas Linn. in central India. Silvae Genetica 53(4): 186-192.

GuptA, S. P. (1994): Statistical methods, XV Ed. Sultan Chand and Sons, Darya Ganj, New Delhi.

HelleR, J. (1996): Physic nut. Jatropha curcas L. Promoting the conservation and use of underutilized and neglected crops. 1. Institute of Plant genetics and Crop Plant Research, Gatersleben/IPGRI, Rome. 66pp.

Johnson, H. W., H. F. RoBinson and R. F. Comstock (1955a): Estimates of genetic and environmental variability in Soyabean. Agron. J. 47: 314-318.

Johnson, H. W., H. F. RoBinson and R. F. Comstock (1955b): Genotypic and phenotypic correlation in soybean and their implication in selection. Agron. J. 47: 477-483.

MathuR, R. S., K. K. Sharma and M. M. S. RAWAT (1984): Germination behaviour of provenances of Acacia nilotica sp. indica. Indian Forester 110: 435-449.

OKoRo, O. O. (1976): Germination of Terminalia ivqrensis seeds source under various conditions of germination.
In 'Seed problem' Proceedings second international symposium on physiology of seed germination. October 1976, IUFRO, Fiji, Japan.

Roy, S. M., R. C. Thapliyal and S. S. Phartyal (2004): Seed source variation in cone, seed and seedling characteristic across the natural distribution of Himalayan low-level pine Pinus roxburghii Sarg. Silvae Genetica 53(3): 116-123.

RoYal Horticulture Society (1966): Colour chart of Royal Horticulture Society, London. L. in Costa Rica. Commonwealth Forestry Review 66: 317-324.

SALZAR, R. and M. QUESADA (1987): Provenance variation in Guazuma ulmifolia L. in Costa rica. Commonwealth Forestry Review 66, 317-324.

SCHMIDT, L. (2000): Guide to handling of tropical and sub tropical forest seeds. Danida forest seed center, Krogerupvej-21, Denmark.

TURNBULL, J. W. (1975): Seed collection - sampling consideration and collection tech. In report of FAO/DANIDA training course of forest seed collection on handling held in Chiang Mai, Thailand, Feb/March, FAO/TF/RAS-11(DEN), FAO, Rome.

VAKSHASYA, R. K., O. P. RAJORA and M. S. RAWAT (1992): Seed and seedling traits of Dalbergia sissoo Roxb.: Seed source variation studies among ten sources in India. Forest Ecology and Management 48: 265-275.

WhitTington, W. J. (1973): Genetic regulation of germination. pp. 5-30 in Seed Ecology, edited by W. HEYDECTER, Butterworth, London,

WiLlAn, R. L. (1985): A guide to forest seed handling with particular reference to the topics. FAO Forestry paper $20 / 2$.

\title{
Optimal Clone Number for Seed Orchards with Tested Clones
}

\author{
By D. LINDGREN ${ }^{1)}$ and F. PRESCHER ${ }^{2), *}$
}

(Received 13 $3^{\text {th }}$ May 2005)

\begin{abstract}
The optimal number of clones in seed orchards is discussed. A model is constructed to maximize a goodness criterion ("benefit") for seed orchards. This criterion is a function of: 1) the number of tested genotypes available for selection and planted in seed orchard; 2) the contribution to pollination from: a) the ramet itself; b) the closest neighbors; c) the rest of the orchard and sources outside the orchard (contamination); 3) variation among genotypes for fertility; 4) frequency of selfing; 5) production of selfed genotypes; 6) gene diversity (= status number); 7) influence of contamination; 8) genetic variation

1) D. LINDGREn, Department of Forest Genetics and Plant Physiology, Swedish University of Agricultural Sciences, S-90183 Umeå, Sweden. Email: Dag.Lindgren@genfys.slu.se.

2) F. PRESCHER, Svenska Skogsplantor AB, Seed production, S-34014 Lagan, Sweden. Email: Finnvid.Prescher@ skogsplantor.se.

*) Corresponding author: Finnvid PRescher.
\end{abstract}

among candidates; 9) correlation between selection criterion (e.g. height in progeny test) and value for forestry (e.g. production in forests from the orchard); and 10) the number of clones harvested. Numeric values of the entries are discussed, and values were chosen to be relevant for scenarios with Swedish conifers (focusing on Scots pine) and for loblolly pine. Benefit was maximized considering the number of clones. The optimum was 16 clones for the Swedish scenario, while less for the loblolly pine scenario. The optimum was rather broad, thus it is not essential to deploy the exact optimum, and an approximate optimum will do. A sensitivity analyses was performed to evaluate the importance of the likely uncertainty and variation in different entries. Quantification of the benefit of gene diversity is important. Other significant considerations are the genetic variance in the goal character and the ability to predict it, as well as the impact of selfing and the variation in reproductive success between clones. Twenty clones is suggested as a thumb rule for Swedish conifers. 
Key words: Gene diversity, selfing, pollination, genetic gain, clone number, seed orchard.

\section{Introduction}

Many of the conifer forests planted today originate from seed orchard seeds. Seed orchards established today usually utilize tested clones. The number of clones deployed is one of the first and most central questions raised when establishing seed orchards. It is an advantage to deploy fewer clones in advanced generation seed orchards because the selection intensity and thus the genetic gain will be higher when fewer tested candidate clones are used. Environmental and legal issues however often increase the number.

Considering the importance and relevance of the number of clones in seed orchards, it has been surprisingly not fully discussed in the literature, and never in depth in a widely read journal paper. We found two titles in a literature search with something like "the number of clones in seed orchards" in the title (LINDGREN, 1974 and HATTEMER et al., 1982). Neither is widely cited (mainly "self-citations") or easily accessible (a proceedings paper and a paper in German).

HATTEMER et al. (1982) focused on the risk of loosing alleles in "domesticated" populations, such as clonal seed orchards. The risk of loosing alleles can be calculated for a number of clones, at least when pollen contamination is ignored, but it is uncertain what relevance this risk may have in forestry.

The North Carolina State University Tree Improvement Cooperative (2001) has recommended 20 to 30 clones when establishing new seed orchards. This was for maximizing rouging flexibility and minimizing inbreeding. Complete removal of 50 to $60 \%$ of the clones was foreseen, and genotypes (or related genotypes) should be separated by about $30 \mathrm{~m}$. A larger number of clones reduces gain and creates problems in orchard management. Clones should occur in approximately equal frequencies to provide rouging flexibility. However, current seed orchards are established with clones with known breeding values and are not designed for rouging, but cone harvest of the lowest ranking clones is not foreseen. Currently often around 20 clones are considered, including a few relatives.

KANG et al. (2001b) reviewed the number of clones in 255 conifer seed orchards in Sweden, Finland and Korea; typically the number was about 90 . In the USA, on an average, there are 24 clones in loblolly seed orchards and 42 clones in slash seed orchards, but the number of clones varies tremendously; there were 6 seed orchards with only 5 to 10 clones (McKEAND et al., 2003). Historical surveys, however, reflect seed orchards established in the past, and not those which will be established in the near future (see below). Many firstgeneration seed orchards have been established with 25 to 40 selections from wild forests (ZOBEL and TALBERT, 1984), which could be reduced to 20 or fewer clones after genetic rouging.

British Columbia has a seed lot rating standard considering diversity based on clonal contributions on the female side. Little additional diversity will be obtained by an "effective number" larger than 7 , and rare alleles cannot assure planting success above that (STOEHR et al., 2004). They have developed the rating protocol further by including modifications to the effective population size calculations in order to reflect the potential relatedness among orchard parents in future advanced generation orchards. Their study suggests that a seed lots $\mathrm{N}_{\mathrm{e}}$ should exceed 10 to be used for reforestation of public land.

KJÆR (1995) suggested that if a species has long rotation length and is normally naturally regenerated, a large number of clones should be used. For safety reason one must always assume that long rotation species will be naturally regenerated. The effective clone number of 20 (following genetic thinning) was considered acceptable if breeding values are known. For elite seed orchards of Scots pine in Finland, twenty clones have been mentioned (NIKKANEN and ANTOLA, 1998).

Forest trees maintain high levels of genetic diversity compared to other species. The significance of this is unclear. Isozyme markers have been widely used for analysis of genetic diversity. Seed orchard clones have a similar genetic diversity as their source populations, although some rare alleles are not well represented in the orchards (e.g. GoDT et al., 2001). By rouging the seed orchards down to 10 clones, they still were able to maintain gene diversity, although allelic richness would decrease (GODT et al., 2001).

Theoretical and empirical data seems to indicate that seed orchards with 20 or more clones should provide the same level of risk as seed collected from the natural population (JoHNSON and LiPOW, 2002). A smaller number of clones could increase the risk somewhat, but it has not been quantified how much.

Most of the studies mentioned above do not quantitatively consider the fact that gain increases as fewer tested clones are used. LINDGREN's analysis (LINDGREN, 1974; in particular Fig. 2) seems to indicate that around six tested clones would be optimal for P. sylvestris. LINDGREN and EL-KASSABY (1989) analyzed the problem with clone number analytically introducing a value for the flexibility to manipulate the seed orchard later. LINDGREN (1989) suggested, based on a reasoning balancing gain with possible disadvantages, that clone numbers down to 12 could be considered in seed orchards with tested clones, and that "effective numbers" down to 8 could be worthwhile.

HoDGE and WHITE (1993) simulated advanced generation seed orchards with particular relevance for P. taeda improvement. They do not make a direct recommendation on clone number, but the clone number used in their analyses ranges between 12 and 40, when clones were deployed in equal proportions.

Clone number in clonal forestry seems to have been more widely discussed than clone number in seed orchards (see e.g. references in AHUJA and LIBBY, 1993), but this discussion has limited significance to clone number in seed orchards.

Theoretical improvements concerning the effective population size of seed orchard crops have improved possibilities to analyze suitable numbers (LINDGREN and 
Mullin, 1998; KANG, 2001). Earlier efforts to formulate the goodness of a seed orchard into a single value, like "group merit" (OLSSON et al., 2001) or "benefit" (SoN et al., 2002) are predecessors of the current study.

The aim of the present study is to develop a relevant quantitative model for the number of tested clones in a clonal conifer seed orchard and to discuss optimum clonal number based on that model.

\section{Methods}

\section{Model development}

The standard method for seed production in an open pollinated seed orchard for conifers (widely applied in e.g. Pinus taeda, . sylvestris, $P$. pinaster, Picea abies) is assumed. Vegetative copies (usually grafts) are produced from a number of selected genotypes chosen among a number of candidates based on test values, usually of their progeny. The grafts are planted in rather wide spacing in a seed orchard, established at a place isolated from unimproved pollen and managed for seed production.

To optimize clone number, a criterion for the value of a seed orchard as a function of clone number and other entries must be formulated. First we discuss these other entries and then a benefit criterion for the orchard where different components and entries are amalgamated.

\section{Assumptions}

- The clones are not inbred and not related.

- Pollen is not a limiting factor for seed set; this is not likely to be the case in seed orchard conditions (SORENSEN and WEBBER, 1997).

- Contaminating pollen from outside the seed orchard is not related to itself, or to the seed orchard clones.

- The fertility can vary among clones. It is assumed that differences from the mean are the same on the male and female side.

More assumptions will be identified below.

\section{Pollen source}

There is selfing pollen from the orchard tree itself, selfing pollen from other ramets belonging to the same clone in the orchard, out-crossing pollen from other clones in the orchard and contaminating pollen (unimproved pollen from outside the seed orchard). The sum of the pollination contributions from different sources is one (Equation 1),

$$
\text { Poll }_{w T r e e}+\text { Poll }_{\text {Neighb }}+\text { Poll }_{\text {SOSelf }}+\text { Poll }_{\text {SOOutcr }}+\text { Poll }_{C}=1
$$

Where:

Poll $_{w \text { Tree }}$ is the share of (self) pollinations originating from the tree considered (on average),

Poll $_{\text {Neighb }}$ is the share of pollinations originating from the closest neighbors, where ramets of the same clone need not be placed. If ramets are placed at random Poll $_{\text {Neighb }}=0$,

Poll $_{\text {SOSelf }}$ is the share of selfing pollinations originating from ramets of the same clone (thus selfing), but not the closest neighborhood,
Poll $_{\text {SOOutcr }}$ is the share of outcrossing pollinations originating outside the closest neighborhood,

Poll $_{C}$ is the share of pollinations originating outside the seed orchard.

$$
\text { Poll }_{\text {SO }}=\text { Poll }_{\text {SOOutcr }}+\text { Poll }_{\text {SOSelf }}
$$

\section{Pollination versus fertilization}

All pollinations do not result in healthy germinable seeds. Observations, on which conclusions concerning pollinations are based, are mostly of the frequency of fertilizations resulting in embryos or seedlings, not pollinations. Nevertheless, the model is expected to be more informative if based on pollination as the primary event. Differences between pollen contribution and fertilizations contributing to the seed crop is that some pollen results in self-fertilization and a selfed zygote may not result in a selfed healthy seed.

\section{Self-pollination}

The frequency of self-pollination among clones is not constant. Some clones produce more pollen than others, and thus produce more self-pollinations. If all clones produced the same amount of seeds, the differences in self-pollination would cancel out, and the frequency of self-pollination would be $1 / n$ on average. Those clones with a high amount of shed pollen also produce a larger percentage of the seeds. Therefore the contribution to self-pollination from other ramets of the same clone is higher compared to if all clones had the same fertility. The self-pollination can be expressed as a function of the "sibling coefficient":

$$
\text { Poll }_{\text {SoSelf }}=\Psi \text { Poll }_{\text {SO }} / n
$$

Where:

$n$ is the number of clones in seed orchard,

$\Psi$ is the sibling coefficient (KANG, 2001).

Often the fertility is different for the male and the female side. For example, KANG et al. (2001a) found correlations of around 0.3 in a clonal seed orchard of $P$. densiflora. Individual clones may be more male or more female. Under a constant sibling coefficient, a low correlation will decrease selfing. It would not be difficult technically to add this to the model, but to avoid additional entries, this has not been considered here. If a greater effect of selfing is foreseen, it is recommended to include this factor in the model.

\section{Paternal contribution to plants}

Selfing pollen is often less efficient in producing viable seeds and healthy seedlings. In conifers this is often because increased zygote lethality, caused by recessive lethal or semi-lethal (Williams and SAVOlainen, 1996). Selfed seeds will have a reduced germination and selfed plants suffer a greater chance to die, be out-competed or discarded before they reach the field. Thus the yield of plants following self-pollination (compared to out-crossing) is reduced by a factor SelfEff. To make the algebra more transparent, this will be referred to only as reduction of fertilization compared to selfing. 
The relative contributions to fertilization (pollen parents) of the different pollination possibilities are summed up by Equation [3]:

$$
\text { Fert }_{T}=\text { SelfEff } * \text { Poll }_{w T \text { Tee }}+\text { Poll }_{\text {Neigh }}+\frac{(n-1+\Psi * S e l f E f f) * \text { Poll }_{S O}}{n}+\text { Poll }_{C}
$$

to facilitate to express individual contributions into fractions.

Self-fertilization. The contribution to the self-fertilizations (or rather the share of selfed plants planted in the forest) of self-pollination is expressed in Equation [4]:

$$
\text { Fert }_{\text {Self }}=\frac{\text { SelfEff } *\left(\text { Poll }_{\text {wTree }}+\frac{\Psi * \text { Poll }_{\text {SO }}}{n}\right)}{\text { Fert }_{T}}
$$

Where:

Fert $_{\text {Self }}$ is the share of selfed seeds (or rather selfed plants planted),

Fert $_{T}$ is the summed fertilization contributions from the different pollination types according to Equation [3].

\section{Goal character for improvement}

The goal character in this study is "value for forestry". That can never be exactly defined, because we do not know the future. It may be visualized as "annual wood production per area", but other possibilities to use the model exist. The effects of selfing and gene diversity should be expressed so they are compatible on the scale of the goal character.

\section{Breeding value}

The most important aspect of the seed orchard crop is the average breeding value (or rather "genetic gain") for the goal character. The candidate genotypes are (arbitrarily) assigned the average breeding value 1 (or equivalently $100 \%$ ). Note that the candidates are improved genotypes and thus the breeding value assigned, as the standard value 1 in this study often is associated with a genetic gain. The selection gain ("response to selection"), which is the increase in genetic gain obtained by selecting, can be predicted as the product of three factors: selection intensity; correlation between measured (observed) and goal values, and the standard deviation of the true values, expressed as the formula [5]

$$
\Delta G=i_{n_{\text {cand }}, n} * r_{T I, \text { cand }} * C V_{A, \text { cand }}
$$

Where:

$\Delta G=$ predicted change in average breeding value for the goal character;

$i_{n_{\text {cand }}, n}=$ the expected selection intensity when selecting the $n$ highest values out of $n_{\text {cand }}$ values sampled from a standardised normal distribution;

$r_{\text {TI,cand }}=$ the correlation between the measured values used as selection criterion and the goal values for the candidates;

$C V_{A, \text { cand }}=$ standard deviation of the goal breeding values for the candidates.

The measured values may be, for example, an index weighting important characters in 6 year-old progeny experiments, and the goal values are breeding values for the economical value of the resulting forest and man- aged under future practice conditions over the range of applications (that means Genotype $\mathrm{X}$ Environment interaction considered).

The factor $r_{T I}$ may be seen as a product of a juvenile mature correlation and a factor expressing uncertainty in the method of calculating this correlation.

\section{Gene diversity}

Group coancestry, $\Theta$ is the loss of gene diversity compared to the forests the initial plus trees were selected (LindGRen and Mullin, 1998). For seed orchards, it is more intuitive to express the gene diversity as an effective population size, status number, $N_{S}$. The two concepts are connected by the formula:

$$
\Theta=\frac{0.5}{N_{S}}
$$

Status number of the seed orchard crop can be expressed as a function of pollen contamination and sibling coefficient by Formula [7] (modified from KANG et al., 2001b).

$$
N_{S}=\frac{n}{\Psi\left(1-\text { Fert }_{C} / 2\right)^{2}}
$$

Where:

Fert $_{C}$ is the fraction of pollen parents (pollen siring seeds, fertilizations) originating outside the seed orchard (pollen contamination).

It is assumed that contaminating pollen from outside the seed orchard is not related to itself, or to the seed orchard clones.

\section{Benefit of a seed orchard}

The goodness criterion or "benefit" of a seed orchard is quantified as fraction of the "benefit" of a hypothetical seed orchard with an infinite number of candidates and no selfing. The formula is constructed as "multiplicative". The "benefit" is calculated in Equation [8] as a product of one factor for the genetic value of the gametes contributed by mothers and fathers (including contamination) and another factor considering diversity loss.

$$
B=B_{G} * B_{G D}
$$

Where:

$B$ is the benefit of the seed orchard;

$B_{G}$ is the genetic factor for the benefit;

$B_{G D}$ is the gene diversity factor for the benefit.

The Gene diversity factor in Formula [8] is quantified by Equation [9].

$$
B_{G D}=1-\text { DivCoeff }^{*} 0.5 / N_{S}
$$

Where:

DivCoeff expresses how much gene diversity is worth.

If no gene diversity has been lost compared to the "wild forest", $B_{G D}$ is one. If DivCoeff is one, it means that a seed crop, which has as little diversity as a homozygous line (equivalents are used in many agricultural fields), has no value. If DivCoeff is 0 , it means that the benefit of a seed orchard crop is independent of its gene diversity, that it does not matter if there is gene diversity or not. 
To express the benefit of genetic gain, the disadvantage of selfing must be quantified. The "production" of the selfed plants will be reduced by a factor Selfprod. Thus, the contribution to "production" of selfed plants (compared to the parent's genetic capacity if no selfing had occurred) is

$$
(1+\Delta G) * \text { Fert }_{\text {Self }} * \text { Selfprod } \text {. }
$$

Where:

Selfprod expresses what fraction of the forest value, a selfed plant produces compared to an outcrossed one;

$\Delta G$ is defined in Formula [5].

The genetic value of a seed orchard crop is clearer when expressed with the mother and father (seed parent and pollen parent, female and male) contributions to gain (including effect of selfing and contamination) expressed as separate terms. However, to simplify the formula, pollen parent contribution to selfing is considered in the first term.

$$
\begin{aligned}
& B_{G}=\frac{\left(1+\Delta G_{\text {mother }}\right)\left(1+\text { Fert }_{\text {Self }} *(2 * \text { Selfprod }-1)\right.}{2}+ \\
& \frac{\left(1+\Delta G_{\text {father }}\right)\left(1-\text { Fert }_{\text {Self }}-\text { Fert }_{C}\right)+\text { Fert }_{C} * G_{C}}{2}
\end{aligned}
$$

Where:

$\Delta G_{\text {mother }}$ is the selection gain for seed parents;

$\Delta G_{\text {father }}$ is the selection gain for pollen parents;

$G_{C}$ is the breeding value of the contaminating pollen (which is normally somewhat lower than 1).

The gain for the pollen parents and the gain for seed parents are equal, provided all clones are harvested, and then the genetic value in Formula [11] can be simplified as:

$$
B_{G}=\frac{(1+\Delta G)\left(1+\text { Fert }_{\text {Self }} *\left(2 * \text { Selfprod }_{-1}-1\right)+\text { Fert }_{\text {Neighb }}+\text { Fert }_{\text {soouce }}\right)+\text { Fert }_{C} * G_{C}}{2}
$$

For the simple case: many clones; no neighborhood consideration; all pollen come from the seed orchard; and status number is high, formula [8] can be expressed as:

$$
B=(1+\Delta G)\left(1-\text { DivCoeff } * 0.5 / N_{S}\right) \approx 1+\Delta G-\text { DivCoeff } * 0.5 / N_{S} .
$$

The appearance of this approximation makes it likely that there is not much difference between a multiplicative model and an additive model.

The factor considering gene diversity is valid for the whole seed crop. Formula [8] expresses a multiplicative model, and it is possible it can be misleading when the value of gene diversity loss is high. Even a linear model can be misleading and the difference between linear and multiplicative is small when the factor expressing the value of loss of gene diversity is not much lower than 1 . But this formula should probably not be used for extreme situations as far as gene diversity is concerned.

The gene diversity following selective harvest can (KANG et al., 2001b) be approximately predicted as

$$
N_{S}=\frac{4 n_{\text {mother }} n}{\left(n+\left(1-\text { Fert }_{C}\right)\left(3-\text { Fert }_{C}\right) n_{\text {mother }}\right) \Psi}
$$

Large $\Psi$ and small number of harvested clones decreases the reliability of the formula.

\section{Spreadsheet}

EXCEL spreadsheets that apply the math and methods developed in this paper are available on the web site managed by DAG LINDGREN, http://www.genfys.slu.se/ staff/dagl/.

\section{Model limitations}

The model developed in this study is not recommended for less than about six clones. Specific clonal interactions and behaviours become too important when factors such as phenology and dominance interactions are taken into account, and generalised heuristic rules for fertility variation of selfing cannot be used. A model for low clonal numbers has to consider individual clonal characteristics rather than averages obtained from other sources.

\section{Likely value of parameters}

The parameters for the main scenario were chosen to be relevant for Pinus sylvestris in Sweden (called the Swedish scenario, (Ss) the figures are good approximations for Pinus contorta and Picea abies also). An alternative scenario was formulated for Pinus taeda in southern United States (called the American scenario, (As)). It is noted when values describing the scenarios differ between the American and the Swedish scenarios.

The parameters, which have to be quantified, are discussed below. The model requires pollination frequencies, but observations usually register reproductively successful pollen only, which has been able to fertilize, and transfer its genes to the embryo of a vital seed.

\section{Sibling coefficient}

A review suggests $\Psi_{(\mathrm{Ss})}=2$ may be used for seed orchard clones as a heuristic rule (KANG et al., 2003). NikKanen and Ruotsalainen (2000) found 1/0.59 $=\Psi_{(\mathrm{Ss})}$ $=1.8$ for a Norway spruce seed orchard. GöMÖRY et al. (2000) found $\Psi_{(\mathrm{Ss})}=1.4-2.2(1 / 0.453-1 / 0.694)$ for three Scots pine seed orchards. A value of 2 was chosen partly for its convenience and based on published data, but it might be slightly too high for well functioning mature seed orchards. However, the ramet number in seed orchards varies widely unintentionally (KANG et al., 2001a), if this variation is considered, the estimate $\Psi_{(\mathrm{Ss})}$ $=2$ can be fair.

\section{Selfing}

Because selfing is connected with disadvantages, evolution often "invents" mechanisms to avoid or reduce selfing. In conifers there are different male and female strobili, and these are physically separated with males dominating in the lower part and females in the higher part of the crown. The females often become receptive a little earlier than the males, but this does not always occur and is probably rather inefficient for completely avoiding selfing. Self-fertilized zygotes often die, mainly because of homozygotization of recessive detrimentals.

Self-pollination cannot be observed directly, but the share of self-fertilizations is detectable by gene marker technology and in other ways, and a number of studies have been done. These studies are not able to separate 
within tree selfing from selfing with other trees of the same clone. Selfed zygotes die or are out-competed to a high degree, so in the mix of pollen in wind pollination, seeds from selfing have a much lower occurrence than seeds from outcrossing, compared to the share of pollen. YAZDANI and LINDGREN (1991) estimated, based on controlled pollinations with mixtures of self and outcross pollen, SelfEff $(\mathrm{Ss})=0.3$.

Based on albino mutants observed in open-pollinated seeds and selfed seeds of $P$. taeda, the coefficient of inbreeding would be 0.031 (SQUILLACE and GODDARD, 1982). Estimates of the percentage of selfed seeds vary in an interval about $2-15$, but the self-pollination is higher and only part of the effect is due to self-pollination within tree.

Selfing is higher in the lower part of the crown, where most of the male flowers are situated (RUDIN and LINDGREN, 1977). SHEN et al. (1981) suggested that about 6 percent of the embryos might result from self-pollination, with a higher frequency in the bottom and fewer in the top of the crown. There are more males in the lower part of the crown, which causes a higher percentage of empty seeds in the lower part (HADDERS, 1972). JOHNSSON (1972) concluded that selfing contributed only $1 \%$ of the seed orchard seeds based on comparison for empty seeds following wind-pollination, selfing and outcrossing. These observations must be interpreted that it is within tree selfing and based on these observations a reasonable estimate is $P o l l_{w T r e e}(\mathrm{Ss})=0.1$. It seems reasonable that larger trees also produce more within tree selfing, thus a higher estimate may be justified when seed orchard trees are large and widely spaced (like P. taeda in southern US, than when their growth is more retarded by pruning (like $P$. sylvestris in Sweden).

Although theoretically possible, selfing in Scots pine occurs at very low levels. Estimates of multi-locus outcrossing rates indicate that over $97.0 \%$ of seedlings will be of an out-crossed nature (BURCZYK, 1998; BURCZYK and CHALUPKA, 1997). Low levels of selfing would not appreciably increase inbreeding depression in gene resource plantations because in conifers most selfed seed are aborted early due to an accumulation of lethal recessives. Moreover, seedlings originating from selfing suffer from a lack of vigour and would be culled from nursery stock prior to planting.

\section{Close neighbors}

The close neighbor trees contribute a part of pollination. For a Scots pine seed orchard, SHEN et al. (1981) found that a single neighbor contributed $31 \%$ of the fertilizing pollen in a case when wind direction and flowering phenology were favorable. The results by RUDIN and EKBERG (1982) did not suggest a large influence from close neighbors. SoRENSEN (1972) predicted, based on a pollen flight model, that the nearest eight trees fertilize $51.7 \%$ of the out crossed ovules of a ramet. LINDGREN (1974) made some estimates compatible with the suggested values and pointed out that no ramet except the four nearest could be expected to contribute more than $6 \%$ of the pollinations. ERICKSON and ADAMS (1989) suggested that lack of complete floral synchrony between near neighbors might limit their influence. Therefore it is suggested that

$$
\text { Poll }_{\text {Neighb (Ss) }}=0.1 \text {. }
$$

Thus, 10 per cent of the pollen comes from a neighborhood which can be kept free of other ramets of the same clone.

\section{Pollen contamination}

The quantitative effect of pollen contamination is usually estimated in the seeds from seed orchards as frequency of embryos or seeds with characters, which suggests that they are the results of fertilization with nonseed orchard pollen. Typical values for pines, including P. taeda and P. sylvestris, in mature seed orchards within the species range seem to be almost 50\% (LINDGREN, 1991 and review by KANG, 2001, Tab. 4). Observations of $\mathrm{Fert}_{C}=0.5$ corresponds to a slightly lower value of $\mathrm{Poll}_{C}$, as selfing pollen will not be effective in fertilization. As a main scenario it will be assumed that $\operatorname{Poll}_{C(\mathrm{Ss})}=0.4$, which lead to Fert $_{C}$ close to 0.5, as often is observed. Therefore:

Poll $_{S O}=0.4=$ Poll $_{\text {SOSelf }}+$ Poll $_{\text {SOOutcr }}$ is what remains.

WHEELER and JECH (1986) estimated a case of interblock "contamination" at $16 \%$, this may give a hint of how large a proportion of the pollen originates from distant parts of a seed orchard.

Pollen contamination produces a lower genetic value than the seed orchard. For the quantification, we should consider a situation where the contaminating pollen is not maladapted, but just has a lower breeding value. For the Swedish scenario if we assume 100\% = untested initial plus trees, which is assumed to be $6 \%$ better than a tree in an improved forest from which the contaminating pollen typically origin (Rosvall et al., 2001), thus for the Swedish scenario $\mathrm{G}_{\mathrm{C}(\mathrm{Ss})}=0.94$. LI et al. (1999) reported that loblolly pine in the southern United States grown from seeds of first-generation seed orchards produced 7-12\% more volume per unit area at harvest than trees grown from seeds of wild forests. The US tree improvement has passed beyond the first generation, and the average candidate worthy of testing, of which the seed orchard selections are drawn (100\%), may be $125 \%$ better than an unimproved tree. But even the contaminating pollen in the industrial plantation regions may now be "improved" to a degree, which deserves consideration (and there may even be clones which are (that common) related so that inbreeding could be considered). For the American scenario we set $\mathrm{G}_{\mathrm{C}(\mathrm{As})}=0.85$.

Rosvall et al. (2001) concluded that pine and spruce seed orchards in Sweden with phenotypically selected plus trees results in $10 \%$ increased production compared to stand seeds. The selection gain because plus trees were chosen, is $6 \%$. Two percent depends on that plus trees are selected from many stands over a large area, while stand seeds suffer somewhat from inbreeding as trees in a natural stand are sometimes related. Two percent of the increase is assigned to a remaining physiological effect of better seeds. These two later factors will not be considered, they are not relevant for clonal number. 


\section{Inbreeding depression following selfing}

Inbreeding depression on height growth of $\mathrm{S}_{1}$ progeny has a large range from zero to almost $50 \%$, averaging $22 \%$, for 20 conifer species (see Table 8.2 in SEDGLEY and GRIFFIN, 1989).

Heterozygosity is often considered as a positive factor, heterozygotes should be less susceptible to diseases and more flexible to changes in the environment. Heterozygosity is diversity within tree (for further discussion see Rosvall, 1999). A measure of change in heterozygosity is inbreeding, thus the effect of selfing here is a measure of the effect of decrease in heterozygosity.

From a practical standpoint, orchard managers need not be very concerned about the yield of selfed seedlings from seed orchards. Admittedly, since selfs are usually inferior in growth rates and less vigorous than cross-pollinated seedlings, they are likely to be culled in the nursery or often will be suppressed and die when outplanted. Even production of non-usable plants and dead trees has a price. Part of the ecological space left open by dead or surpressed selfed trees can be used by other trees. It is estimated that the loss caused by inbreeding is the same as the coefficient of inbreeding, which is 0.5 for selfing. A $22 \%$ decrease in height growth would mean more than $50 \%$ lost in volume production, but there are other factors, which probably more than compensates for this, but it is a handy heuristic rule that inbreeding loss is equal to inbreeding depression. Because inbreeding depression is a very real loss, and gain is a more uncertain estimate, it seems right to have an estimate of inbreeding loss, which is likely not to underestimate the disadvantage. SelfProd ${ }_{(\mathrm{Ss})}=0.5$ will be used.

\section{Prospects for genetic gain}

The genetic variance in breeding values has been thoroughly studied. CORNELIUS (1994) made a compilation of 67 published papers for heritability and genetic variance in economically important characters. The $C V_{A}$ for tree volume was $20.3 \%$, for tree height $8.5 \%$ and diameter $8.6 \%$. However, the values for parameters in progeny tests have a limited importance for the estimation of gain in value for real forests. It is the parameters for the goal character and correlations between the observed and the goal that matters. Experiments deal usually with rather young trees, on a limited number of sites, and under conditions, which may statistically simulate "real" forestry. For production at mature age, over the range of environments, a seed orchard is intended to serve for $P$. sylvestris, $P$. contorta and $P$. abies in Sweden has been estimated at $\sigma_{A \text {, cand (Ss) }}=0.125$ (Rosvall et al., 2001; JANSSON et al., 1998), and this value includes an adjustment because test environments vary statistically and in reality a stand grows only in one environment. The correlation between height measurements in a number of progeny test at young age compared with mature production has been assumed to be $r_{j m(\mathrm{Ss})}=0.7$ (Rosvall et al., 2001). It may be slightly higher, because earlier estimates of juvenile-mature correlation were much influenced by LAMBETH (1980), which gave phenotypic correlations, but recently calculations of genetic correlations (LAMBETH and DiLL, 2001 and GWASE et al., 2000 ) indicate that a little higher juvenile mature correlation could be used. Another reason for using a slightly higher correlation is that selection does not consider only height, and the best selection index can be assumed to be better correlated with the final value rather than height only. In practice, $r_{T I}$ may be different for different candidates, and become larger if trials are measured at older age. Estimates are usually hampered by the lack of experiments, which are both relevant and sufficiently old. Many estimates in the literature therefore may be too high. Maternal effects, seed effects "aftereffects", or differences in the amount or effects of inbreeding may cause what is interpreted as additive gene action. Some differences may be due to the fact that provenances and adaptation varies more in experimental plantations than in seed orchard selections. We believe that American breeding values are somewhat more accurate, because conclusions are made later, closer to full rotation and because sites are less variable in Sweden, thus $r_{T I(\mathrm{As})}=0.8$.

Selection intensity is important for gain and this is a function of the number of available clones. For the Swedish scenario it may be regarded as typical that $n_{\text {cand }(\mathrm{Ss})}=300$ clones with breeding values estimated from field tests, which are available for the third cycle seed orchards (cf. Rosvall et al., 2001), although there are variations in seed orchards serving different areas, and depending on how selections best adapted for slightly different areas, which will be dealt with. The number of candidates increases when more tests become available. Candidates may in reality be related (as sibs or parent-child), and that gives rise to constraints and modifications, which will not be considered here.

\section{Gene diversity}

Genetic diversity in forest regeneration material has been discussed (SKRÖPPA, 1996). Some of what is meant by gene diversity refers to gene diversity within genotypes (heterozygosity), and as far as this study is concerned, this can be seen as equivalent to inbreeding, which does not occur in this study (apart from selfing), thus specific aspects on heterozygosity need not be considered here.

There are a number of possible advantages, if plants from a seed orchard are different:

- The biological production is likely to be higher because the site will be more fully utilized.

- If one component (progeny) of a diverse crop fails, other components can take over the ecological space available.

- The risk that the stand is severely damaged by a biological or physical incident is reduced.

- A disease or pest can be assumed to spread slower in a non-uniform crop.

These possible advantages of gene diversity seem supported by a large number of experiments with annual crops (e.g. BowDEN et al., 2001) and a few with forest trees. The suggested benefits are small and variable. The economically driven agriculturists usually prefer a uniform crop because of a higher economic value of a 
Table 1. - Highest likely quantification of the value of gene diversity (DivCoeff) likely to be compatible with observations.

\begin{tabular}{|c|c|c|c|}
\hline Experience & $\begin{array}{l}\text { Maximum } \\
\text { loss }\end{array}$ & $\begin{array}{l}\text { Group } \\
\text { coancestry, } \\
\Theta\end{array}$ & DivCoeff \\
\hline $\begin{array}{l}\text { Deployment as half sibs. E.g. } 59 \text { percent of all loblolly } \\
\text { pine plantations are established as single open-pollinated } \\
\text { family blocks and few problems reported (McKeand et } \\
\text { al. 2003). }\end{array}$ & $<5 \%$ & $\begin{array}{l}0.13 \text { (Kang } \\
\text { et al 2002) }\end{array}$ & $<0.35$ \\
\hline $\begin{array}{l}\text { Deployment of full sibs. (E.g. Carson } 1986 \text { concerning } \\
P \text { radiata in New Zealand). }\end{array}$ & $<10 \%$ & 0.25 & $<0.4$ \\
\hline $\begin{array}{l}\text { Monoclonal forestry. The experience of clonal forestry } \\
\text { programs was reviewed e.g. by Sonesson et al. } 2001\end{array}$ & $<10 \%$ & 0.5 & $<0.2$ \\
\hline $\begin{array}{l}\text { Mixing agricultural lines. This praxis can increase } \\
\text { expected production somewhat, e.g. Bowden et al. } 2001 \text {. }\end{array}$ & $=2.5 \%$ & 0.5 & $=0.05$ \\
\hline
\end{tabular}

uniform product and simpler management, in spite of the predicted advantages of genetic diversity. It may be argued that gene diversity helps the planted trees to get a higher share of sites resources leaving less to other organisms, thus high gene diversity may be considered environmentally doubtful. The advantages listed are seldom large or uncontroversial, and are often worth only a few percent in production. If diseases caused by low diversity spread to other stands the harm could be greater. It is problematic to quantify the importance of gene diversity on a scale compatible with production. This is mainly because there are few reports based on a large number of representative objects, and it is doubtful if this should be expected, even if there were considerable advantages with mixtures. Table 1 was constructed to quantify likely influence of gene diversity. The quantification is often based on a lack of reported observations indicating considerable harm. Losses caused by a lack of diversity is assumed to be proportional to group coancestry and derived as the product of group coancestry and the proportionality constant, DivCoeff. Thus DivCoeff can be derived by knowing the loss and the group coancestry of the object. For most objects an estimate depends on how large the loss is, which seems likely to be compatible with absence of frequent observations and debate about the loss.

\section{The stand resulting from the use of seed orchard seed} will be more suitable for self-generation.

This can be quantified. The expected inbreeding level in the resulting stand is the group coancestry of the seed orchard crop. If there is no contamination or volunteers and the inbreeding depression is $F$, the DivCoeff, could be as high as 1 . Because it is unlikely that an improved forest will be replaced by natural regeneration, and if that happens frequently, the production would then have fallen drastically, perhaps to zero meaning that raw material must come from somewhere else, and then the production losses by inbreeding depression would not be seen as negative. The evolutionary potential would have been lost in such a forest, but probably there are other more efficient sources of evolutionary potential than intensive plantations, and if it was replanted it would not have any evolutionary potential at all. Volunteer plants and pollen contamination in the new forest are arguments to reduce the value of diversity loss.

- In a general sense, to conserve genetic diversity is regarded as something good and politically correct.

- To appear environmental friendly because it has an economical benefit for the forester (e.g. the operation is more likely to get approved in green certification).

- A low status number can mean that the clones are less representative, especially if genotype $\mathrm{X}$ environment interaction is high. Dominance can cause deviation of the seed crop performance compared to the breeding value based predictions. Flowering phenology changes may be more important. The sibling coefficient is less reliable when applied to a low number. Thus a seed orchard with a higher status number would be a more predictable seed source. This argument seems still stronger, if correlated characters are considered.

- A higher status number widens the options to get additional gain out of the seed orchard by actions, which exploits the gene diversity, like selective cone harvest. This is considered here by considering rouging.

To assign a value to DivCoeff depends on the "political" climate and can hardly be made using purely "scientific" considerations. For Pinus taeda in America, there is a long and positive experience with plantings with a low diversity, and authorities or the public are not very interested in the question of the gene diversity in the productive forest, therefore a low DivCoeff $(\mathrm{As})=0.2$ seems justified. Besides that, selfing efficiency is very low and thus the major reason for having many clones becomes the option to rouge. In Sweden a much more evident debate exists involving authorities about clone number in seed orchards and clonal mixtures, Sweden has very little experiences of low diversity forestry, thus DivCoeff $_{(\mathrm{Ss})}=0.4$ will, somewhat arbitrarily, be used.

\section{Selective harvest}

It is desirable that a seed orchard has flexibility for later changes (LINDGREN and EL-KASSABY, 1989). Such a change is a selective harvest. Thus if not all seeds are needed (e.g. as the seed orchard is successful in produc- 
Table 2. - Optimal clone number (in bold) maximizing estimated seed orchard benefit (B) considering different entries. Calculations are made for a main scenario (Swedish Scots pine, values in italics); an American loblolly pine scenario and alternative scenarios exchanging one or - for pollination sources - a few entries compared to the main scenario.

\begin{tabular}{|c|c|c|c|c|c|c|c|c|c|c|}
\hline \multirow{3}{*}{$\begin{array}{l}\text { Factor } \\
\text { Explanation } \\
\text { Optimal clone number for } \\
\text { major scenarios and } \\
\text { alternative pollen scenarios }\end{array}$} & \multirow[t]{2}{*}{ Symbol } & \multicolumn{9}{|c|}{ Scenarios } \\
\hline & & \multirow{3}{*}{$\begin{array}{l}\text { Swedish } \\
\text { main } \\
\mathbf{1 6 . 1 0}\end{array}$} & \multirow{3}{*}{$\begin{array}{l}\text { American } \\
\mathbf{8 . 2 4}\end{array}$} & \multicolumn{4}{|c|}{ Alternative Swedish pollination scenarios } & \multirow{6}{*}{\multicolumn{3}{|c|}{$\begin{array}{l}\text { Alternative Swedish Scenarios } \\
\text { except alternative pollination } \\
\text { scenarios (to the left). The } \\
\text { figures give deviation from main } \\
\text { scenario and (in bold) the } \\
\text { optimal clone number.. }\end{array}$}} \\
\hline & $N$ & & & 21.17 & 12.69 & 16.77 & 17.63 & & & \\
\hline \multicolumn{6}{|l|}{ Share of pollen source } & & & & & \\
\hline Within the Tree itself & Poll wree $_{\text {Tree }}$ & 0.1 & 0.1 & 0.1 & 0.1 & 0.2 & 0.1 & & & \\
\hline Close Neighborhood & Poll $_{\text {Neigh }}$ & 0.1 & 0.1 & 0.1 & 0.1 & 0 & 0 & & & \\
\hline $\begin{array}{l}\text { Outside the seed orchard } \\
\text { (Contamination) }\end{array}$ & Poll $_{\mathrm{C}}$ & 0.4 & 0.4 & 0 & 0.6 & 0.4 & 0.4 & & & \\
\hline \multicolumn{4}{|l|}{ Other factors } & \multicolumn{4}{|c|}{ As in main scenario } & & & \\
\hline $\begin{array}{l}\text { Number of candidates } \\
\text { available for selection }\end{array}$ & $n_{\text {cand }}$ & 300 & 300 & & & & & $150-14.32$ & 600 & $-\mathbf{1 7 . 8 3}$ \\
\hline Sibling coefficient (see text) & $\Psi$ & 2 & 2 & & & & & $1-\mathbf{9 . 7 3}$ & 3 & -21.97 \\
\hline $\begin{array}{l}\text { Selfed plants yield, } \\
\text { Efficiency as a fraction of } \\
\text { self-pollinations }\end{array}$ & SelfEff & 0.3 & 0.1 & & & & & $0 \quad-\mathbf{1 1 . 3 6}$ & 1 & -23.86 \\
\hline Selfed plants Production & SelfProd & 0.5 & 0.5 & & & & & $0 \quad-\mathbf{2 0 . 9 3}$ & 1 & -11.12 \\
\hline $\begin{array}{l}\text { Drop in production is Diversity } \\
\text { Coefficient times drop in Gene } \\
\text { Diversity }\end{array}$ & $\begin{array}{ll}\text { y } & \text { Div } \\
\text { e } & \text { Coeff }\end{array}$ & 0.4 & 0.2 & & & & & $0-7.60$ & 1 & -27.56 \\
\hline $\begin{array}{l}\text { Genetic worth of } \\
\text { Contamination }\end{array}$ & $G_{c}$ & 0.94 & 0.85 & & & & & $0.8-\mathbf{1 6 . 0 4}$ & 1 & -16.93 \\
\hline $\begin{array}{l}\text { Coefficient of Variation for } \\
\text { breeding value }(\boldsymbol{A})\end{array}$ & $C V_{A}$ & 0.125 & 0.125 & & & & & $0.05-31.45$ & 0.2 & -11.84 \\
\hline $\begin{array}{l}\text { Correlation between goal } \\
\text { (True) and measurement } \\
\text { (Index). }\end{array}$ & $r_{T I}$ & 0.7 & 0.8 & & & & & $0.4-\mathbf{2 4 . 0 6}$ & 0.85 & -14.13 \\
\hline Share of the clones Harvested & $H$ & 1 & 1 & & & & & $0.5-20.9$ & & \\
\hline
\end{tabular}

ing cones) only the better clones could be harvested for cones. It seems reasonable that a seed orchard should be planned so that it is rather optimal even if only half of the seeds are harvested, $H_{(\mathrm{Ss})}=0.5$.

\section{Alternative scenarios}

For each entry, some variations were tried while keeping the other constant. For some entries (e.g. pollinations) entries can only be changed as a group. An alternative main scenario was done for Pinus taeda in southeastern United States, when several of the entries were set to other values.

\section{Results}

The numeric results are presented in Table 2 and Figure 1 , and discussed below.

\section{Pollination patterns}

The different pollination patterns tested did not have a major influence. To reduce selfing by a seed orchard design, which guarantees that ramets of the same clone are not neighbors, insignificantly reduces the optimal number of clones. Thus, it is not a strong argument to have many clones and that it is possible to have them more widely spaced. Heavy pollen contamination also reduces the optimal number. The breeding value of the contaminating pollen is not important for clonal number.

\section{Number of candidates}

An increased candidate number weakly favors a higher number of selections.

\section{Selfing consequences}

The consequences of self-pollination were highly important for clonal number. If selfing does not result in seeds or if seeds from selfing do not result in inbreeding depression, there is little need to avoid selfing with a high clonal number. Therefore it is important that these factors are considered only for the specific seed orchard situation.

\section{Gene diversity}

The importance placed on gene diversity has a strong effect on the optimal clonal number; it increases rapidly if the importance of gene diversity is increased.

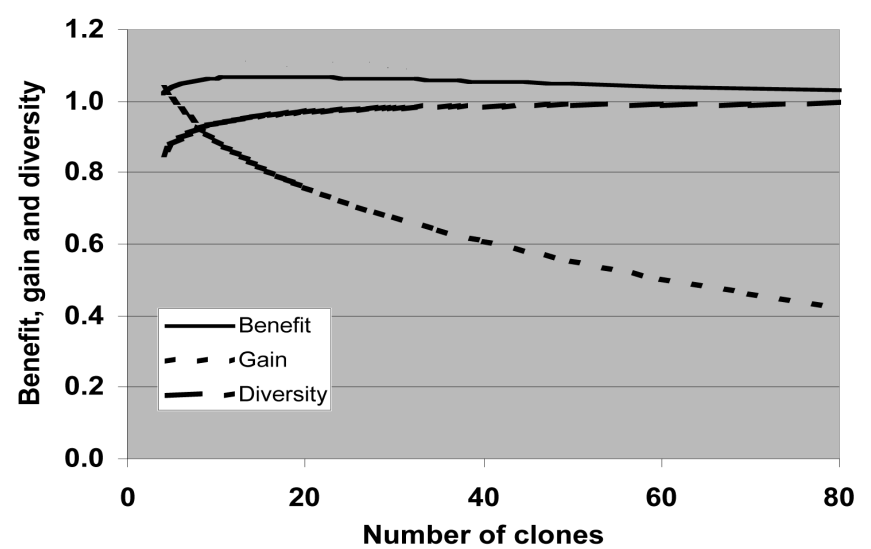

Figure 1. - The relationship between clonal number, benefit, gain (multiplied by 5 ) and gene diversity. When clonal number increases; the gene diversity increases slowly approaching 1 ; the genetic gain drops and the benefit reaches a maximum. The maximum seems flat, considerable deviations are not critical. The scenario is Swedish except only 200 candidates. 


\section{Genetic gain}

High genetic variation and strong correlations between measured values and breeding values for benefit favor a low optimal clonal number.

\section{The fraction of seeds harvested}

A small fraction of seeds harvested increases the optimum clone number somewhat.

\section{The number of clones is flexible around the maximum}

Probably the exact number of clones is unimportant (Figure 1). The maximum is broad, only a few percentages will be lost if the chosen number of clones deviates somewhat from the optimal. The advantages and disadvantages will cancel out. But of course, even one percent gain has an immense economical value!

\section{Discussion}

\section{Proportions instead of number of clones}

Actually the problem stated in the title of this paper is not well formulated; it should rather be "the proportion of the ramets for different clones (LINDGREN and MATHESON, 1986), which could be optimally related to their characteristics, such as their breeding value". This principle is seldom implemented, and to consider that increases in the degrees of freedom and makes the results less transparent. However, the unequal deployment of clones is likely to be more accepted in advanced generation orchards. This means having a seed orchard with "an effective number of clones" similar to what is recommended in this study, however, if the census number of clones is 25 or $50 \%$ higher and unequally deployed, then the seed orchard becomes more optimal than the equal deployment suggestions presented below.

\section{Effective number of clones}

The number of selections is actually the number of clones, although flowering variations and variations in ramet number is accounted for by the sibling coefficient $\Psi$. Status number of the seed orchard crop is calculated and when used for gene diversity (Figure 1), it is not explicitly given. To make the procedure optimal, some additional selections should be included and the clones should be used proportional to their breeding values. This would increase gain, which may be slightly overestimated, and it would increase sibling coefficient, but $\Psi$ may be slightly underestimated. To claim that the numbers of selections refer to the effective number of clones (in the meaning considering variable ramet number) is not likely to be very misleading.

\section{Selfing}

If selfing is reduced, a smaller number of clones is justified. Some clones are more male and others more female (ZieHE and HATTEMER, 1985), and intentional selection of such clones reduces the selfing. Clones differ widely in their self-fertility (in contrast to the assumptions of calculation), and this can be tested. If self-fertile clones are selected against, selfing is reduced. In the future, inbred clones may be used in seed orchards and such clones can be expected to be less self-fertile (GRIF-
FIN and LINDGREN, 1985). It is a possibility that inbreeding depression is lower in more self-fertile clones, thus the effects of selfing may be overestimated.

\section{Relatives in seed orchards}

If the choice is between, for example, two full sibs or only the best of them in double the proportion, it offers some advantages to choose the latter alternative. The breeding value of the seed orchard will be higher if the best of two are used and the inbreeding loss is probably lower. The efficiency of pollination with relatives is considerably higher following sib mating than selfing. Few selfs will survive to the productive forest. It is easier to isolate ramets of one clone than of two related clones by non-related ramets. But on the other hand, two relatives contribute more to diversity than a single unrelated one. Thus, to include some related clones seems more justified when gene diversity is considered important. If a large number of clones is enforced by some minimum number rule, that probably leads to more relatives and thus more harm by inbreeding depression in seed orchards. In this situation the genomes derived from the best trees would probably be used in many clones instead of just one. Future generation seed orchards and seedling seed orchards comprises many relatives, and the inbreeding issue will be important and almost unavoidable, this study does not deal with these situations.

\section{First batch of seed orchards}

Many selections are done at an early stage of a breeding program. In seed orchards with phenotypic selections from unimproved forests, there are good reasons to use all these selections in seed orchards:

- It is easier to get a sufficient number of scions from a larger number of trees.

- Inclusion of the selection in orchards is a way of conserving them; in the initial stage of a tree breeding program land and routines for clonal archives may not yet be established.

- It is easier to fund forest tree improvement if progeny-testing of clones can be justified by the need to manage existing orchards.

- It can be argued that if a sufficient broad genetic base is maintained.

- Almost no gain is lost, as phenotypic plus tree selections in practical forests have similar predicted breeding values.

The advantage of a few clones is mainly the higher genetic gain; in the seed orchards with initial selections this advantage is insignificant. It is when advanced seed orchards are established that low clonal numbers becomes beneficial.

\section{Roguing}

In the Western Gulf Forest Tree Improvement program, rouging improved the performance of loblolly pine seed orchards by an average of $2.9 \%$ in breeding values for volume growth (BYRAM et al., 1998). ROSvALL et al. (2001) estimated the realizable gain from genetic thinning, aiming at removing the poorest half of the clones, was normally $2-3 \%$. The gain can under favorable con- 
ditions increase to about $5 \%$ by moving ramets to other positions in the seed orchard, which may be possible, but expensive, in order to retain all the good trees that happen to be growing adjacent to each other. This could be compared with something in the magnitude of $12 \%$ additional gain in a newly established seed orchard. Rouging was a recommended, or at least foreseen, at an early stage in forest tree breeding history, when the seed orchard clones were not tested prior to planting, but this paper deals with tested clones, and then there is not that much additional gain to be captured by retesting them, or measuring the same tests again at older age. The justification for using many clones just to remove them later may be questioned, at least at an intensive level and with particular tests just to guide the thinning,

\section{Selective Harvest}

The best part of a seed orchard may be used more intensively in other ways than genetic thinning. If the seed orchard produces more seeds than needed, the seed orchard manager may choose to harvest seed from only the best ones (for P. taeda the seed orchards are often designed with that option in mind). Additional pollination may boost the genetic value of the best. If the genetic value is the same as at establishment, the seed orchard manager could have chosen a smaller number of clones. But if additional information appears (trials become older, the weighting of characters may change), it may not be possible or practical to change the seed orchard composition later.

\section{Family blocks}

Pines in southern USA are often deployed in half sib family blocks (MCKEAND et al., 2003). This study is not primarily headed towards that situation, and additional arguments and considerations may be required. However, around $40 \%$ of the plantations with loblolly pine do not use family blocks.

\section{Variance}

The genetic variance among clones in the seed orchard in untested characters depends on clonal number as (1$1 / \mathrm{N})$, thus the same expression as the gene diversity. Genetic variance can also be seen as an alternative measure of genetic diversity, and its similarity with gene diversity strengthens the usefulness of that concept. This expression is not strongly dependent on clonal number.

\section{Mixing seeds}

If seed orchards have a few clones, and the gene diversity of the crop is regarded as low, the problem can be remedied by mixing seeds from several orchards, even if this has practical problems as to get permission from forest authorities for trading of the mixture. If, however, the problem is the inbreeding depression following selfing, mixing seeds will not help.

\section{Beta diversity}

In this study gene diversity within stands is considered. But on a landscape or a regional level genetic diversity among stands is also important. It could be an advantage if stands are different, because biological or physical disasters would cause less regional damage. Epidemics are expected to spread faster if stands are similar. If a large number of clones is required by a minimum rule that probably makes the different orchards serving a landscape or region more related, and thus reduces the beta diversity. If a small number of clones are accepted, different seed orchard designers at different times in different organizations working against different goals will end up with a very different short-lists of the best clones with less common relatives.

\section{Pollen contamination}

Selfing pollen has a low fertilization efficiency and its presence will increase the share of zygotes with fathers outside the seed orchard. Therefore as Fert ${ }_{\text {Cont }}$ increases with decreasing clonal number, this will reduce the value of the seed orchard crop. The higher the clonal number, the worse the contaminating pollen is. In Swedish seed orchards serving Scots pine for the interior north, pollen contamination reduces adaptation. Concerning $P$. taeda in southern US, where the candidates are second-generation tested clones, they are more superior to the contaminating pollen.

\section{Flexibility for later changes}

The planting of clones in a seed orchard creates future options. The seed orchard can be rouged; selective harvest can be used; artificial mass pollination can be applied to the most successful clones; the progeny of the best clones can be multiplied by vegetative propagation. These options can be based on information about the clones, which was not available when the seed orchard was established. More clones in the seed orchard create more options. This future flexibility was considered in the benefit equation by LINDGREN and EL-KASSABY (1989), here this advantage is not quantified or explicitly considered, it is too difficult to put a value on it and it can be considered absorbed in the DivCoeff factor.

\section{Other factors which affect the optimal number of clones}

Seed orchard considerations about clones, like production of seeds and pollen, should be considered besides breeding values in selecting clones, thereby reducing the selection intensity. Some clones may fail after establishment, for example, because of incompatibility, a technical malfunction in the system or other losses. Then the real number of clones would be lower than that planned. It may thus be justified to plan for a higher number than the optimal as an insurance against such events. In the evolution of forestry and seed orchard management, it is a risk to make large steps, e.g. to make drastic cuts in clone numbers compared to existing managerial experience. This contributes to doubts about very low numbers. Because the penalty for using a higher number than optimal seems low (Figure 1), and there is uncertainty in the exact optimum, somewhat higher number than seemingly optimal can be used. Seed orchards may also have functions in breeding such as clonal archives, or for crossings or collecting wind polli- 
nated progenies. This may be an argument to increase the number of clones. It may be marginally more difficult to establish a seed orchard with many clones, but on the other hand the lack of material for grafting may justify somewhat higher clonal numbers. Costs were not considered in this study (progeny testing expenses are viewed as a sunk cost). Because the optimal number of selections is lower if there are fewer candidates, inexpensive programs may contribute to slightly lower number of clones in seed orchards.

\section{Suggestion}

The suggestion applies only to deployment in equal proportions, which is not optimal, and to unrelated, tested clones. For Swedish conifer seed orchards 20 clones can be suitable in a standard situation. For P. taeda in US 10 clones may be optimal. These suggestions may be reasonably optimal for an average case, but in individual cases, when more case specific information is available, higher or lower numbers may be best. Legal rules must permit flexibility for such variation. Revisions are needed about once a decade as the accumulated gain increases, selection becomes more constrained by relatedness and decisions become more complex as material from different sources and background must be compared.

\section{Acknowledgements}

Ola Rosvall and KYU-SuK Kang has read the manuscript and contributed valuable comments. The actual value of the entries for Swedish Scots pine was discussed with Ola Rosvall and CURT AlmQUist, the values for loblolly with Tim Mullin. A considerable part of this job was done when DAG LINDGREN was a visiting scientist at Raleigh supported by GUNNAR and LILLIAN NICHOLSON Fellowship and to a small degree Föreningen för Skogsträdsförädling.

\section{References}

AhuJA, M. R. and W. J. LIBBy (editors) (1993): Clonal Forestry Vol. I. Genetics and Biotechnology. SpringerVerlag. Berlin Heidelberg, 277 pp.

Bowden, R., J. Shoyer, K. Roozeboom, M. ClaAsen, P. Evans, B. Gordon, B. Heer, K. Janssen, J. Long, J. Martin, A. Schlegel, R. SEars and M. Witt (2001): Performance of wheat variety blends in Kansas. Kansas State University Agric. Extension Bull. 128, 6 pp.

BuRCZYK, J. (1998): Mating system variation in a Scots pine clonal seed orchard. Silvae Genetica 47: 155-158.

BURCZYK, J. and W. CHALUPKA (1997): Flowering and cone production variability and its effect on parental balance in a Scots pine clonal seed orchard. Ann. Sci. For. 54: 129-144.

Byram, T. D., F. E. Bridgwater, G. D. Gooding and W. J. LowE (1998): $46^{\text {th }}$ progress report of the cooperative forest tree improvement program. Texas Forest Service, 23pp.

CARSON, M. J. (1986): Control-pollinated seed orchards of the best general combiners - a new strategy for radiata pine improvement. In: Proc. Plant Breeding Symposium DSIR 1986 (ed. Williams, T. S., WratT, G. S.). Agronomy Society of New Zealand Special Publication No. 5 pp 144-149.
CoRnelius, J. (1994): Heritabilities and additive genetic coefficients of variation in forest trees. Can. J. For. Res. 24: 372-379.

ERICKSON, V. J. and W. T. ADAMS (1989): Mating success in a costal Douglas-fir seed orchard as affected by distance and floral phenology. Can J For. Res 19: 1248-1255.

Godt, M. J. W., J. L. Hamrick, M. A. Burke and J. H. Williams (2001): Comparisons of genetic diversity in white spruce (Picea glauca) and jack pine (Pinus banksiana) seed orchards with natural populations. Can J For. Res. 31: 943-949.

GÖMÖRY, D., R. BRUCHANIK and L. PAUle (2000): Effective population number estimation of three Scots pine (Pinus sylvestris L.) seed orchards based on an integrated assessment of flowering, floral phenology, and seed orchard design. For. Genet. 7: 65-75.

GRIFFIN, A. R. and D. LindGREN (1985): Effect of inbreeding on production of filled seed in Pinus radiata experimental results and a model of gene action. Theor. Appl. Genet. 71: 334-343.

Gwaze, D. P., F. E. Bridgewater, T. D. Byram, J. A. Wooliams and C. G. Williams (2000): Predicting ageage genetic correlations in tree breeding programs: a case study of Pinus taeda L. Theor. Appl. Genet. 100: 199-206.

HadDERs, G. (1972): Pollination in Scots Pine seed orchards. Årsbok institutet för skogsförbättring 111-139.

Hattemer, H. H., H. R. Gregorius, M. Ziehe and G. MullER-STARCK (1982): Klonanzahl forstlicher Samenplantagen und genetische Vielfalt. In: German, Number of clones in forest seed orchards and genetic multiplicity. Allgemeine Forst- und Jagdzeitung 153: 183-191.

Hodge, G. R. and T. L. White (1993): Advanced-generation wind-pollination seed orchard design. New For. 7: 213-236.

Jansson, G., Ö. DAnell and L.-G. Stener (1998): Correspondence between single-tree and multiple-tree plot genetic test for production traits in Pinus sylvestris. Can. J. For. Res. 28: 450-458.

JoHnsson, H. (1972): The frequency of self-fertilization in a seed orchard. Unpublished mimeograph.

JoHnson, R. and S. LIPOW (2002): Compatibility of breeding for increased wood production and longterm sustainability: the genetic variation of seed orchard seed and associated risks. In: Proceedings Wood compatibility initiative workshop, number 18: 169-179.

KANG, K. S. (2001): Genetic gain and gene diversity of seed orchard crops. Acta Universitatis Agriculturae Sueciae. Silvestria 187. 75pp (+ 11 chapters).

KANG, K. S., A. D. BilA, A. M. HARJU and D. Lindgren (2003): Estimation of fertility variation in forest tree populations. Forestry 76: 330-344.

Kang, K. S., A. M. HaRJu, D. Lindgren, T. Nikkanen, C. AlmKVIST and G. U. SUH (2001a): Variation in effective number of clones in seed orchards. New For. 21: 17-33.

Kang, K. S., D. Lindgren and T. J. Mullin (2001b): Prediction of genetic gain and gene diversity in seed orchard crops under alternative management strategies. Theor. Appl. Genet. 103: 1099-1107.

KJÆR, E. D. (1995): Assessment of genetic variation in clone seed plantations - illustrated with an example from Sitka spruce. In: Danish. Dansk Skovbruks Tidskrift. 80: 57-77.

LI, B., S. McKeAnd and R. WeIR (1999): Tree improvement and sustainable forestry - impact of two cycles of loblolly pine breeding in the USA. For. Genet. 6: 229-234. 
LAMBETH, C. (1980): Juvenile-mature correlation in Pinaceae and implications for early selection. For. Sci. 26: 571-580.

Lambeth, C. and L. A. Dill (2001): Prediction models for juvenile mature correlations for loblolly pine growth traits within, between and across test sites. For. Genet. 8: 101-108.

LINDGREN, D. (1974): Aspects of suitable number of clones in a seed orchard. Proc of the IUFRO joint meeting of working parties on population and ecological genetics, breeding theory and progeny testing. Stockholm, published by the Royal College of Forestry, Stockholm, Sweden. p 293-305.

LiNDGREN, D.(1989): Genetisk diversitet, klonantal och fröplantager. Sveriges Skogsvårdsförbunds tidskrift 4/87: 3-13.

LINDGREN, D. (Ed.) (1991): Pollen Contamination in Seed Orchards. Proceedings of the Meeting of the Nordic Group for Tree Breeding 1991. Swedish University of Agricultural Sciences. Department of Forest Genetics and Plant Physiology. Report 10: 1-120.

LiNDGREN, D. and Y. A. EL-KASSABY (1989): Genetic consequences by combining selective cone harvesting and genetic thinning in clonal seed orchards. Silvae Genetica 38: $65-70$.

LindGren, D. and T. J. Mullin (1998): Relatedness and status number in seed orchard crops. Can. J. For. Res. 28: $276-283$.

LindGREN, D. and A. C. MAtheson (1986): An algorithm for increasing the genetic quality of seed from seed orchards by using the better clones in higher proportions. Silvae Genetica 35, 173-177.

McKeand, S., T. J. Mullin, T. Byram and T. White (2003): Deployment of Genetically-Improved Loblolly and Slash Pines in the South. J. For. 101(3): 32-37.

NIKkANEN, T. and S. RUOTSALAINEN (2000): Variation in flowering abundance and its impact on the genetic diversity of the seed crop in a Norway spruce seed orchard. Silva-Fennica. 34: 205-222.

NikKanen, T. and J. ANTOLA (1998): Männyn valiosiemenviljelysten perustamisperiaatteet. (Principles of establishment of elite seed orchards in Scots pine). In Finnish. Metsätieteen aikakauskirja 3/1998: 421-428.

North Carolina State University TReE Improvement Cooperative: Tree Improvement Manual. Mimeographed documentation (2001).

Olsson, T., D. LindGREN and B. Li (2001).: Balancing Genetic Gain and Relatedness in Seed Orchards. Silvae Genetica 50: 222-227

Rosvall, O., G. Jansson, B. Andersson, T. Ericsson, B. Karlsson, J. Sonesson and L.-G. Stener (2001): Genetiska vinster i nuvarande och framtida fröplantager och klonblandningar. Genetic gain from present and future seed orchards and clone mixes. SkogForsk, Redogörelse $\mathrm{nr} 1$.

RosvalL, O.(1999): Enhancing Gain from Long-Term Forest Tree Breeding while Conserving Genetic Diversity. Acta Universitatis Agriculturae Sueciae. Silvestria No. $109,65 \mathrm{pp}$
Rudin, D. and I. EkBERG (1982): Genetic structure of open-pollinated progenies from a seed orchard of Pinus sylvestris. In: Population genetics of forest trees. A Proceedings of symposium held in Helsinki 1981. Silva Fennica 16(2): 87-93.

RUDIN, D. and D. LINDGREN (1977): Isozyme studies in seed orchards. Studia Forestalia Suecica 139: 23 pp.

Ruotsalainen, S. and D. LindGREN (2001): Number of founders for a breeding population using variable contribution. For. Genet. 8: 57-67.

SHEN, H.-H., D. RUDIN and D. LINDGREN (1981): Study of the pollination pattern in a Scots pine seed orchard by means of isozyme analysis. Silvae Genetica 30: 7-15.

SKRøPPA, T. (Ed.) (1996): Genetisk diversitet i foryngelsematerialer: nordisk seminar holdt på Honne Konferansesenter, Biri, for Nordisk Skogbruks Frø- og Planteråd 14.-15. november 1995 Aktuelt fra Skogforsk 1996-11.

Son, S.-G., K. S. KAng, D. LindGren and J.-O. HyUn (2002): Qualification for the value of seed orchard considering breeding value and seed productivity. Journal of Korean Forestry Association 91(5): 601-608.

Sonesson, J., R. Bradshaw, D. Lindgren and P. StÅHL (2001): Ecological evaluation of clonal forestry with cutting-propagated Norway spruce. SkogForsk Report 1, 59 pages.

SoRENSEN, F. C. (1972): The seed orchard trees as a pollen sampler: a model and example. USDA For Serv Res Note PNW-175, 175: 1-11.

Sorensen, F. C. and J. E. WebBer (1997): On the relationship between pollen capture and seed set in conifers. Can. J. For. Res. 27: 63-68.

Squillace, A. E. and R. E. Goddard (1982): Selfing in clonal seed orchards of slash pine. For. Sci. 28: 71-78.

Stoehr, M., J. WebBer and J. Woods (2004): Protocol for rating seed orchard seedlots in British Columbia: quantifying genetic gain and diversity. Forestry 77: 297-303.

YAZDANI, R. and D. LINDGREN (1991): The impact of selfpollination on production of sound selfed seeds. In: Biochemical markers in the population genetics of forest trees (ed. Fineshi, S., Malvolti, M. E., Cannata, F. and HattemeR, H. H.). SPB Academic publishing bv. The Hague, The Netherlands. pp. 143-147.

Williams, C. G. and O. SAVOlainen (1996): Inbreeding depression in conifers: implication for breeding strategy. For. Sci. 42: 102-117.

WheELER, N. C. and K. S. JECH (1986): Pollen contamination in a mature Douglas fir Seed orchard. Conference proc. IUFRO conference, joint meeting of working parties Breeding theory, Progeny testing and Seed orchards. Williamsburg pp. 160-171.

ZieHE, M. and HATTEMER, H. H. (1985): Recent findings on asymmetry effects in the sexual reproduction of forest trees. Allgemeine Forst- und Jagdzeitung 11, 225-231.

Zobel, B. and J. TALBERT (1984): Applied forest tree improvement. John Wiley \& Sons, New York, USA. 505 pp.

Herausgeberin: Bundesforschungsanstalt für Forst- und Holzwirtschaft: Schriftleitung: Institut für Forstgenetik und Forstpflanzenzüchtung, Siekerlandstrasse 2, D-22927 Grosshansdorf — Verlag: J. D. Sauerländer's Verlag, Finkenhofstrasse 21, D-60322 Frankfurt a. M. Anzeigenverwaltung: J. D. Sauerländer's Verlag, Frankfurt am Main. Satz: Satz- und Grafikstudio König, Marburg — Druck: Druckerei Wenzel, Marburg — Printed in Germany. 